http://dx.doi.org/10.12775/szhf.2019.035

\author{
Marta ŚLIWA \\ UnIVERSITY OF WARMIA AND MAZURY IN OLSZTYN \\ E-MAIL: MARTA.SLIWA@UWM.EDU.PL \\ ORCID: 0000-0001-8796-511X
}

\title{
The Scottish Enlightenment. Links Between Philosophy and Medicine in the Activities of Philosophical Societies
}

For a few decades, there have been some attempts to redefine the Enlightenment, which shows that the epoch does not make a closed and fully explained unit for its researchers. The era of the Enlightenment is believed to be a beginning of cultural changes that shaped the modern mind. There are still questions about the ideas constitutive of the epoch, their background, or even the time span of the epoch, its character, and the place of philosophy in it. The Enlightenment was an intellectual movement which stressed such values as the reliability of evaluation, a need to control one's feelings, but mostly following common sense. What made a characteristic feature of the $18^{\text {th }}$-century philosophy was an enthusiastic belief in rational-grounded natural knowledge, which can be achieved by the light of the reason.

The Scottish Enlightenment is a particular example of the Enlightenment, commonly defined as an intellectual spark following a process of intellectual accumulation and dissemination connected with significant development and improvement of both economic and cultural conditions. This intellectual 
movement is called 'the Scottish Age of Improvement' and led to the formation of a new paradigm of Enlightenment philosophy. That incredible success of the Scottish Enlightenment is a result of a coincidence of various factors that are usually omitted. The Enlightenment discovers subjectivity, a single individual, but at the same time it shows that human subjectivity is intertwined in various social relations. The Scottish Enlightenment was viewed through David Hume, Adam Smith, or Henry Home, but a new approach - 'a conversational model' of intellectual history proposed by Sarah Hutton in relation to the $17^{\text {th }}$-century British philosophy (British Philosophy in the Seventeenth Century, 2017) - challenges dealing with philosophy only through single writers and their most important works. This concept provides new tools to re-read the phenomenon which the Enlightenment was and allows us to have a fresh look at it.

Basing on the conversational model, it is possible to study the background that becomes a foreground here. It assumes that the conversation is participated in not only by the greatest philosophers but also by their printers, recipients of their works, as well as by the activity of men of science, institutions, societies with their varied members. An example is provided here by Hutton who asks us to listen to individual voices engaged into this conversation. It allows for noticing and actually directing attention to social and political determinants of a particular intellectual solution. That leads to involved philosophy and a kind of philosophy directed towards naturalism. That new paradigm of philosophy may be created only in a close relation to empirical sciences, sciences that were its cultural environment ${ }^{1}$.

The perspective underlined in this way allows for formulation the following hypotheses: (1) the success of a new philosophy was possible due to unique social conditions of Scotland; (2) it was a laboratory, as within relatively small borders and in a readable geopolitical condition a unique

1 She writes: "I focus on individuals rather than particular branches of philosophy, or philosophical themes, and I treat celebrate 17th-century philosophy as ongoing conversation, as a means of setting philosophers in relation to one another. The conversational model allows voices to be heard which would otherwise be discounted. By this means I provide what might be called a 'thick description' of seventeenth-century intellectual culture, setting marginal and 'major' thinkers within a more integrated account of seventeenth-century philosophy, which attempts to view it in its own terms, taking account of institutions, and the modes of circulation of ideas" $(2017,2)$. 
construct was formed which can show, as in the lens, what happened in other Enlightenments. The new paradigm of dealing with philosophy that answers the question whether the Enlightenment is a work of outstanding individuals or a collective work leads to the next hypothesis: (3) is the result of such collective work, particularly if it was shared with non-philosophers, the fact that it was possible to develop in such a way only such a type of philosophy that provides a justification and a basis for developing empirical sciences?

What is analysed in this paper is the connection between philosophical thinking and medicine based on activity of institutional bodies such as societies and philosophical clubs ${ }^{2}$. Special focus is placed on cooperation between philosophers and physicians of Aberdeen, Edinburgh and Glasgow societies. Some activities of the Glasgow Philosophical Society, the Aberdeen Philosophical Society - the Wise Club, and the Philosophical Society of Edinburgh is presented, including the active participation of physicians in those societies with a description of related topics discussed at meetings and, as a result, some linked publications. It must be underlined that philosophical clubs presented here are all illustrating the same phenomenon; however, there are significant differences in the way they operated.

A brief analysis performed here allows us to show how the philosophical knowledge and rational thinking became the background for medicine diagnoses and at the same time, how developing medical science influenced philosophical thinking of those days. The interaction between the men of science in Scotland, the scientists who very often knew each other, led to that incredible development in $18^{\text {th }}$-century Scotland.

2 The study of history of science and medicine in 18th-century Scotland crystalized in 1970s with the most influential paper by John Christie "The Origins and Development of the Scottish Scientific Community 1680-1760”, History of Sciences 12 (1974). Christie wants to explain the flowering of scientific activities referring to a complex context that includes economics, politics, and culture. 'Distinctive philosophical and educational programme' that encompasses the pursuit of natural science and medicine in the period related to significant development and improvement of both the economic and cultural spheres. The crucial role in cultivation of natural knowledge was played by universities, clubs, student societies and more formal bodies like the Royal Society of Edinburgh (Science and medicine in the Scottish Enlightenment, ed. Charles W. J. Withers and Paul Wood (East Lothian: Tuckwell Press, 2002), 2). 
One of the most exclusive scientific societies in Scotland at that time was the Aberdeen Philosophical Society called also the Wise Club ${ }^{3}$. All its fifteen members were men of science, including philosophers, mathematicians, theologists, and physicians. All documents by the Wise Club - The Rules of the Philosophical Society in Aberdeen, The Minutes, The List of Questions, Transactions of the Wise Club - have been preserved. The contents of both The Minutes and The List of Questions are particularly important for this analysis, as they allow us to focus on activities of the physicians from the Wise Club.

John Gregory (1724-1773) was a professor of philosophy and then a physician and mediciner at King's College in Aberdeen. He was a quite active member of the society who delivered six discourses. The first five were collected in his Comparative View of the State and Faculties of Man with Those of Animal World (1765). The first tree discourses discuss the faculties of men and animals (The State of Man Compared with that of Lower Creation, An Enquiry into those Faculties which Distinguish Man from the Rest of the Animal Creation), the next two focus on the 'influence of religion upon human nature' and the 'foundation of taste in music'. His final discourse examines 'the prolongation of human life and retardation of old age. Gregory's eight questions cover criticism, economics, education, medicine, and natural philosophy. Two interesting ones, showing his wide interests, include:

1. What Are the Distinguishing Characteristics of Wit and Humour? (handled on the $8^{\text {th }}$ of May);

2. Whether the Art of Medicine, as It Has Been Usually Practised, Has Contributed to the Advantage of Mankind? (handled on the $12^{\text {th }}$ of July 12).

3 Its activity is very well documented. Lewis H. Ulman in Minutes of the Aberdeen Philosophical Society, 1758-1773, presented the $18^{\text {th }}$-century Aberdeen with the peculiar role played by the Wise Club. The history of the Society was spoken by the words of their founders, which include: The Rules of The Philosophical Society in Aberdeen, The Minutes, List of Questions, transaction of the Wise Club. Minutes of the Aberdeen Philosophical Society, 1758-1773, ed. by Lewis H. Ulman, Aberdeen University Studies Aberdeen University Studies, 158. (Aberdeen: Aberdeen University Press), 1990. See also, E. H. King "A Scottish 'Philosophical' Club in the Eighteen Century", Dalhousie Review 50 (1971): 201-214; Marta Śliwa, "Philosophical Societies in the Scottish Enlightenment”, Ruch Filozoficzny 74 (2018): 107-117. 
In 1764, Gregory left Aberdeen for Edinburgh, where, in 1766, he became a professor of the practice of physics at the University of Edinburgh. He was also granted membership in the Philosophical Society of Edinburgh and the Royal Medical Society. He also published the following books: Observations of the Duties and Offices of a Physician, and on the Method of Prosecuting Enquires in Philosophy (1770), Elements of the Practice of Physic (1772) ${ }^{4}$.

David Skene (1731-1770) was another physician, very active one at meetings of the societies. He was the Dean of the Faculty at Marischal College in Aberdeen. Lewis H. Ulman puts his discourses in four groups: Philosophy of Mind, Nature of Happiness, Natural History, and Methods of Classifying Plants. He also proposed a dozen questions on economics, education, government, language, law, and moral philosophy.

Some interesting ones include:

1. What Are the Proper Characters of Enthusiasm and Superstitions and Their Natural Effects on the Human Mind? (handled on the $25^{\text {th }}$ of January);

2. How Far Human Actions Are Free or Necessary? (handled on the $24^{\text {th }}$ of May and the $14^{\text {th }}$ of June);

3. What Are the Advantages That Mankind Peculiarly Derives from the Use of Speech? (handled on the $13^{\text {th }}$ of March 1766);

and a very up-to-date question:

4. Whether Brutes Have Souls; and if They Have, Wherein Do They Differ from the Human? (handled on the $15^{\text {th }}$ of November 1764).

What is interesting is the fact that there were no questions connected with his own specialisation; however, he wrote an abstract of a conversation regarding a biological question proposed by Campbell: Can the Generation on Worms in the Bodies of Animals be Accounted for on the Common Principles of Generations? He never published his works but regularly corresponded with leading naturalists of the day (John Ellis, John Hope, Linnaeus, Thomas Pennant, John Walker). However, several of his dissertations were collected

${ }^{4}$ Minutes of the Aberdeen Philosophical Society, 1758-1773, Aberdeen University Studies Aberdeen University Studies, 158, ed. Lewis H. Ulman (Aberdeen: Aberdeen University Press, 1990), 28. 
by his nephew - these make a valuable documentation of the $18^{\text {th }}$-century medical practice, the natural history and geology of northeast Scotland, and the deliberations within the Wise Club.

George Skene (1742-1803) was another physician of the Wise Club. He was a professor of natural philosophy and then a professor of civil and natural history at Marischal College, as well as a physician. He provided only four discourses, the first one on the 'abuse of mechanical reasoning in natural philosophy', the rest on the 'theories and practice of physick' He also presented five questions concerning education, physics, and one dealing with physiology and medicine. Probably his most interesting one was: Whether Men Become Degenerate in Point of Size and Strength, or Has the Modern Method of Living Increased the number of Diseases or Altered their Nature? (handled on the $9^{\text {th }}$ of April 1764). He did not publish any of his works 5 .

All the questions presented here, discussed by all those mediciners, make only a small percentage of the issues discussed during their meetings - the matters that triggered long and heated disputes. The scope of their topics was very wide and, as it has been already mentioned, scientific in their assumptions. Often questions of a purely philosophical nature were discussed - such notes from Thomas Reid's Inquiry or Alexander Gerard's Essay on Taste have been preserved ${ }^{6}$. The questions by the members of the elite Philosophical Society of Aberdeen indicate some close relations between medicine and philosophy, which confirms its naturalistic background.

When searching for connections between medicine and philosophy and analysing the activities of the philosophical societies, the Glasgow Literary Society cannot be omitted. It was a generalist body that was the most important $18^{\text {th }}$-century society gathering men of science in Glasgow. The record of society proceedings is fragmentary; however, it is known that medical and scientific topics were discussed. For example, Alexander Stevenson asked: How Far the Mind Ought to Be an Object of Attention in the Cure of Diseases?

5 Ibidem, 40.

6 See, Kathleen Holcomb, "Reid in the Philosophical Society", in: The Philosophy of Thomas Reid, ed. Melvin Dalgarno \& Eric Matthews (Kluwer Academic Publishers, 1989), 413; Marta Śliwa, "Philosophical Societies in the Scottish Enlightenment", Ruch Filozoficzny 74 (2018): 112-113; Margaret Lee Wiley, "Gerard and the Scots Societies", Studies in English 20 (1940): 134. 
During the latter part of the $18^{\text {th }}$ century, medicine gained some greater importance in the Glasgow Literary Society. The most active participants in the society of that time were: Thomas Charles Hope, who presented a discourse: The Application of Pneumatic Chemistry in Medicine; James Jeffray, who presented several topics in anatomy; Richard Millar, who spoke on the use and effects of drugs, as well as on medicine and materia medica in the medieval period; Robert Freer, who delivered a series of discourses on fevers; and finally Robert Cleghorn, who presented and discussed diabetes and quack medicines with 86 patient case records (dating from December 1785 to February 1818$)^{7}$. As it can be seen above, in 1790 s, the society became an important venue for the presentation of medical research.

A unique place on the map of the $18^{\text {th }}$-century Scotland had Edinburgh. The capital was full of life and variety and served as a place of presenting and exchanging new ideas. In the 1760s, Edinburgh was known as 'Athens of the North'.

The Society of Improving Arts, and Science and Particular Natural Knowledge, commonly known as the Philosophical Society of Edinburgh (PSE), makes an outstanding example of a society showing a direct connection with medicine and philosophy and, at the same time, focused on social aspects. The society was established in 1737 as an enlargement of the Medical Society founded in 1731 . The idea was to create more general learned society dedicated to a pursuit of natural knowledge and Scottish antiquities, devoted to natural philosophy and such scientific fields as medicine, natural history, and antiquities ${ }^{8}$. The Philosophical Society of Edinburgh is perceived as a perfect example of an enlightened society, with following activities related to medicine: 1) publishing - two volumes of Medical Essays and Observation and Literary, edited by Alexander Monro, or a journal entitled Medical and Philosophical Commentaries, which may be perceived as one of the main achievements of the society, as it facilitated exchanging information with foreign members of the society or non-resident Scots; 2) discussed topics - the analysis of the known topics of discussion in the Philosophical Society of Edinburgh shows

7 Ed. Charles W. J. Withers and Paul Wood, Science and medicine in the Scottish Enlightenment, 2002: 255.

8 Roger L. Emerson, “The Philosophical Society of Edinburgh 1737-1747”, The British Journal of History of Science 12, no. 2 (1979): 155. 
the interest of medicine: in 1737-1747 there are 7 topics related to medicine, which is $10 \%$ of the total number, known and conjectured topics of medicine - 37 , which is $20 \%$ of the total number; in $1748-1768$ we see a huge increase of interest as there are 62 medicine related topics, which is $54 \%$ of the total number, known and conjectured topics of medicine - 84 , which is $41 \%$ of the total number; and finally in 1768-1783 there are only 5 topics, which is $12 \%$ of the total number (technology $-9 / 22 \%$; chemistry - $6 / 15 \%$ ), known and conjectured topics of medicine -27 , which is $22 \%$ of the total number (technology - 14 / 12\%; chemistry - 15 / $12 \%$; botany - 20 / 17\%).

In 1778, William Cullen wrote in the Memorial for the Philosophical Society of Edinburgh: 'The Philosophical Society of Edinburgh was formed with most excellent design of promoting Natural Knowledge, and of doing credit to the Genius and Scientific industry of the country'. This shows exactly how broadly the term 'philosophy' was defined and how it was related to natural science and to medicine itself.

When observing the activity of philosophical societies in $18^{\text {th }}$-century Scotland, especially the Wise Club, the Glasgow Literary Society, and the Philosophical Society of Edinburg, a huge role they played in shaping the new philosophical paradigm may be seen. A noticeable correlation between the way of dealing with philosophy and its content should be pointed out here. An agreement with naturalism in philosophy results from its involvement into empirical sciences. That provides a basis for formulating a thesis that if philosophy is combined with natural sciences, it is going to have a team dimension, clearly visible in activity of philosophical societies of that time. It reinforces the idea that the Scottish Enlightenment does indeed have an empirical natural science character reflected for example in David Hume's 'science of human nature' approach. However, the concern remains whether it is possible to talk about one resulting from another and a dependency between them. Thus, it is justified to ask a question resulting from those analyses - a question about a new paradigm of philosophy dealt with involvement and modelled on the Scottish Enlightenment. But does it provide us with a more general reinterpretation of the Enlightenment as opposed to what is

9 Roger L. Emerson, “The Philosophical Society of Edinburgh 1768-1783”, The British Journal of History of Science 18, No. 3 (1985): 264. 
distinctive in the Scottish Enlightenment compared with the more rationalistic approaches of the Enlightenment elsewhere? This issue, however, needs further and more detailed examination.

\title{
Bibliography
}

Emerson Roger L. 1979. “The Philosophical Society of Edinburgh 1737-1747”. The British Journal of History of Science 12. No. 2: 155-191.

Emerson Roger L. 1981. "The Philosophical Society of Edinburgh 1748-1768". The British Journal of History of Science 14. No. 2: 133-176.

Emerson Roger L. 1985. "The Philosophical Society of Edinburgh 1768-1783". The British Journal of History of Science 18. No. 3: 255-303.

Christie John. 1974. "The Origins and Development of the Scottish Scientific Community 1680-1760". History of Sciences 12: 81-141.

Hutton Sarah. 2015. British Philosophy of the Seventeenth Century. Oxford: OUP.

Holcomb Kathleen. 1989. "Reid in the Philosophical Society". In: The Philosophy of Thomas Reid. Ed. Melvin Dalgarno and Eric Matthews, 413-420. Kulwer Academic Publisher.

Lee Wiley Margaret. 1940. "Gerard and the Scots Societies". Studies in English 20: 132-136.

Ulman Lewis H. 1990. Minutes of the Aberdeen Philosophical Society, 1758-1773. Aberdeen University Studies 158. Aberdeen: Aberdeen University Press.

Śliwa Marta. 2018. "Philosophical Societies in the Scottish Enlightenment". Ruch Filozoficzny 74: 107-117.

Withers Charles W. J., Wood Paul. 2002. Science and medicine in the Scottish Enlightenment. Tuckwell Press Ltd.

Science and medicine in the Scottish Enlightenment. 2002. Ed. Charles W. J. Withers and Paul Wood, Tuckwell Press Ltd.

\begin{abstract}
What is analysed in this paper is the connection between philosophical thinking and medicine based on activity of institutional bodies such as societies, clubs or voluntary institutions. Special emphasis will be placed on cooperation between philosophers and physicians of Aberdeen, Edinburgh and Glasgow societies. Some activities of the Glasgow Philosophical Society, the Aberdeen Philosophical Society -
\end{abstract}


the Wise Club, and the Philosophical Society of Edinburgh will be presented, including the active participation of physicians in those societies with a description of related topics discussed at meetings and, as a result, some linked publications. A brief analysis performed here allows us to show how the philosophical knowledge and rational thinking became the background for medicine diagnoses and, at the same time, how developing medical science influenced philosophical thinking of those days, and created a new philosophical paradigm. The interaction between the men of science in Scotland, the scientists who very often knew each other, led to that incredible development in 18th-century Scotland.

Keywords: Scottish Enlightenment, philosophical societies 